ISSN 1392-3196 / e-ISSN 2335-8947

Zemdirbyste-Agriculture, vol. 104, No. 4 (2017), p. 359-368

DOI 10.13080/z-a.2017.104.046

\title{
Effect of storage technology on the chemical composition of apples of the cultivar 'Auksis'
}

\author{
Vitalijs RADENKOVS, Karina JUHNEVICA-RADENKOVA \\ Institute of Horticulture, Latvia University of Agriculture \\ Graudu 1, 3701 Dobele, Latvia \\ E-mail: vitalijs.radenkovs@lvai.lv
}

\begin{abstract}
In this study, we evaluated the influence of 1-methylcyclopropene (1-MCP) treatment and ultra-low oxygen (ULO)-controlled atmosphere conditions: $2.0 \% \mathrm{CO}_{2}$ and $1.0 \% \mathrm{O}_{2}$ (ULO1), and $2.5 \% \mathrm{CO}_{2}$ and $1.5 \% \mathrm{O}_{2}$ (ULO2) on the changes in chemical composition in the apples of one of the commercially available and the most consumerpreferred cultivar 'Auksis' during long-term storage. This study was conducted from 2012 to 2014 at the Institute of Horticulture, Latvia University of Agriculture in Dobele. The results of the current research evidence that in many cases the chemical composition of 'Auksis' apples depends on the weather conditions (growing season) and storage technology. In terms of storage technology, a better preservation of soluble solids was achieved when ULO conditions and 1-MCP treatment were applied. Moreover, findings reveal that polyphenols present in 'Auksis' apples remained unchanged after six months' storage under ULO conditions. While due to further ripening process in control and 1-MCP treated apples the content of polyphenols increased. The harvest time is the key factor influencing the total pectin content, while, during six months' storage the main factors affecting the content of pectin were the growing season and storage technology. Analysis of variance showed that the content of vitamin $\mathrm{C}$ in 'Auksis' apples depended mainly on the weather conditions, whereas post-harvest vitamin $\mathrm{C}$ losses are affected by harvesting time and storage technology.
\end{abstract}

Key words: 'Auksis', harvesting time, Malus domestica, phenolics, ultra-low oxygen, vitamin C.

\section{Introduction}

The positive impact of fruit consumption on human health and well-being is mainly due to nutrients and non-nutrient bioactive compounds present (Thilakarathna, Rupasinghe, 2013). Fruit quality is affected by genetic background and environmental conditions, cultural and developmental pre-harvest factors (Skic et al., 2016). One of the most important factors determining fruit quality at-harvest and during long-term storage is the degree of maturity. The harvest time is always a trade-off where the main issues are the storability of fruit or quality. The harvesting of unripe apples is not recommended due to lack of nutrients, while overripe apples are also low in nutritional value mainly due to ongoing metabolic activity and related biochemical changes (Bangerth et al., 2012). To ensure the highest fruit quality at the end of long-term storage, apples must be harvested when mature but not when fully ripe (DeLong et al., 1999). The Streif method, which comprises the determination of such characteristics as flesh firmness, starch hydrolysis degree and soluble solids concentration can be applied as a final harvest window for cold and ULO storage (DeLong et al., 1999; Hewett, 2006; Kingston, 2010).

Between harvest and consumption of apples many biochemical reactions take place that in general are regulated by ethylene - growth hormone. Some of these biological changes are essential, in particular depolymerisation or hydrolysis of long starch molecules into simple sugars and degradation of acids, leading to reduction of acidity. However, some of those processes are undesirable (respiration and transpiration), since they lead to quality loss during post-harvest storage (JuhņevičaRadenkova, Radenkovs, 2016 a). Previous studies have shown that consumers associate quality of apples not only with their firmness, juiciness and sweetness, but also are being increasingly concerned about nutritional quality and health-protecting compounds in fruit (Kevers et al., 2007; Vilaplana et al., 2006). Nutritional quality and degree of healthful constituents of fruits are related to contents of vitamins, minerals, dietary fibre and phytochemicals with antioxidant properties, such as phenolic compounds (Awad, De Jager, 2003). The composition of these nutrients and the concentration depend on the cultivar, pre-harvest environmental and cultural factors, stage of maturity at-harvest and post-harvest regime and duration (Kevers et al., 2007). In addition, responses of apple fruit to storage conditions are very specific and vary depending on many factors, such as pre-harvest climatic conditions (air temperature, relative humidity,

Please use the following format when citing the article:

Radenkovs V., Juhnevica-Radenkova K. 2017. Effect of storage technology on the chemical composition of apples of the cultivar 'Auksis'. Zemdirbyste-Agriculture, 104 (4): 359-368 DOI 10.13080/z-a.2017.104.046 
amount of precipitations), genotype differences, maturity stage at-harvest (Drudze, 2003; 2005). According to literature, low temperature is the most important factor in maintaining quality and extending the cold storage and shelf-life of fruits and vegetables after harvest (Tano et al., 2007). However, environmental conditions such as gas composition in storage rooms also play a crucial role. Storage life of fruits can be extended through reduced $\mathrm{O}_{2}$ and elevated $\mathrm{CO}_{2}$, by means of controlled atmosphere (Juhneviča-Radenkova, Radenkovs, 2016 b). A modified atmosphere might delay intensity and severity of deterioration, those caused by biochemical, physiological and microbiological factors (Juhnevica-Radenkova et al., 2016). The controlled atmosphere storage coupled with low temperature storage can reduce respiration and ethylene synthesis rates; by that, preserve softening of the fruits along with the changes related to ripening and senescence (Johnston et al., 2002). In addition, to expensive storage under controlled atmosphere conditions that has both advantages and disadvantages (Raffo et al., 2009), there is a less-expensive and very promising technique for apple quality preservation that can compete with controlled atmosphere storage such as 1-MCP treatment (Juhñeviča-Radenkova, Radenkovs, 2016 a). An inhibitor of ethylene action 1-MCP is an effective tool for maintaining fruit quality during postharvest cold storage and shelf-life (Sisler et al., 1996). Although the above-mentioned techniques generally had been characterised as an effective tools, the efficacy of $1-\mathrm{MCP}$ and controlled atmosphere storage in maintaining apple quality factors is cultivar dependent (Bai et al., 2005). Hence this research was performed in order to evaluate the influence of 1-MCP treatment and ultralow oxygen conditions on the changes in chemical composition during long-term storage of one of the commercially available and the most consumer-preferred cultivar 'Auksis' apples.

\section{Materials and methods}

Research time and place. This study was conducted from 2012 to 2014 at the Processing and Biochemistry Department of the Institute of Horticulture, Latvia University of Agriculture in Dobele (latitude $56^{\circ} 36^{\prime} 35.5^{\prime \prime} \mathrm{N}$, longitude $23^{\circ} 17^{\prime} 57.6^{\prime \prime} \mathrm{E}$ ).

Information on weather conditions. Data were recorded at the weather station in Dobele (latitude $56^{\circ} 36^{\prime} 35.0^{\prime \prime} \mathrm{N}$, longitude $23^{\circ} 17^{\prime} 58.7^{\prime \prime} \mathrm{E}$ ), Latvia.

Weather conditions. Weather in the vegetation period is an important factor influencing fruit quality at-harvest and during post-harvest storage. The weather conditions (air temperature, precipitation level and relative air humidity) determine the harvest time. Under the conditions of southern Latvia, cultivar 'Auksis' apples generally are picked at the beginning of the first ten-day period of September. Hence, in the present study apples in 2012 were harvested on September 6 (the $1^{\text {st }}$ harvest) and 11 (the $2^{\text {nd }}$ harvest), while in 2013 on September 10 (the $1^{\text {st }}$ harvest) and 14 (the $2^{\text {nd }}$ harvest). As can be seen from data depicted in Figure 1, in 2013, throughout the vegetation period the air temperature was significantly higher (mean temperature $13.6^{\circ} \mathrm{C}$ ) than in 2012 (mean temperature $12.8^{\circ} \mathrm{C}$ ), except April and September.

Materials used for research. Apples of commercially available and widely grown cultivar 'Auksis' were chosen for the experiments. Apple trees



Figure 1. Mean monthly air temperature, precipitation and relative humidity during vegetation period 20122014

were grafted on the rootstock B9 and grown in the orchard according to integrated system at the same conditions. Ripening stage of the fruits was assessed by starch index using starch iodine test and Streifs' index:

$$
\text { Streifs' index }=\frac{\mathrm{F}}{\mathrm{SSC} \times \mathrm{SI}},
$$

where $\mathrm{F}$ is firmness, $\mathrm{kg} \mathrm{cm}^{-2}$; $\mathrm{SSC}-$ content of total soluble solids (TSS), ${ }^{\circ} \mathrm{Bx}$; SI - starch index (on a scale from 1 to 10). Harvested fruit met the requirements for fruit intended for long term storage in Latvia (Drudze, 2003; 2005).

Protocols of apples harvesting and preparation for a long-term storage as well as conditions selected for ultra-low oxygen (ULO) storage can be found in Juhņeviča-Radenkova and Radenkovs (2016 b). The treatment with 1-methylcyclopropene (1-MCP) was implemented according to Wawrzyńczak et al. (2007).

Chemical analysis. Ten apples were individually used for the analysis of soluble solids content $\left({ }^{\circ}\right.$ Brix - $\left.{ }^{\circ} \mathrm{Bx}\right)$, total acids content $(\%)$, vitamin $\mathrm{C}$ content $\left(\mathrm{mg} 100 \mathrm{~g}^{-1}\right)$, total phenolic content $\left(\mathrm{mg} 100 \mathrm{~g}^{-1}\right)$, pectin

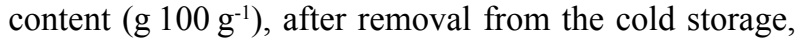
cold storage +1-MCP and controlled atmosphere conditions ULO1 and ULO2. Titratable acidity (TA) was determined using standard method (EN 12147:1996) and quantified by titration of $1 \mathrm{ml}$ of juice (automatic titration DL 21) (Mettler Toledo, Switzeland) with $0.1 \mathrm{M} \mathrm{NaOH}$ to a $\mathrm{pH} 8.1$, expended amount of $\mathrm{NaOH}$ was expressed in percentage of malic acid. Soluble solids content was determined using standard method (EN 12143:1996). Ten apples of each cultivar were selected and grinded with a hand blender Bamix ${ }^{\circledR}$, model SwissLine (Liechtensteinn, Switzerland) into puree and further the content of soluble solids (in ${ }^{\circ} \mathrm{Bx}$ ) was determined using a digital electronic refractometer type Pal-1 (Japan). The content of vitamin $\mathrm{C}$ was determined in the form of ascorbic acid (AAE) using standard method (EN 14130:2003), calculated from the calibration cure and the results were expressed as $\mathrm{mg}$ $100^{-1} \mathrm{~g}$ fresh weight $(\mathrm{FW})$. The total phenolic content (TPC) were determined by a spectrophotometric method provided by Singleton et al. (1999), calculated from the calibration curve and the results were expressed as mg of gallic acid equivalent (GAE) per $100 \mathrm{~g} \mathrm{FW}$. All extracts were made in triplicate. The total pectic compounds were determined by a photometric method provided by Shelukhina and Fedichkina (1994) and the results were expressed as $g$ of galacturonic acid equivalent (GALAE) per $100 \mathrm{~g} \mathrm{FW}$. 
Statistical analysis. Data analysis was carried out using the General Linear Model functions in the statistics programme $I B M \circledR S P S S \circledR 20.0$ (SPSS Inc., USA). The obtained data were analysed using descriptive statistics. Significant differences were determined using a two-way analysis of variance $(A N O V A)$ and multivariate analysis of variance $(M A N O V A)$. Analysis was done considering the main factor influence (storage conditions, the growing season, harvesting time or interaction of them) on the fruit quality. The significance of differences was determined at $p<0.05$. Mean and standard deviation values were calculated for all parameters. In order to understand more about relationship between the variables and the clustering group principal component analysis (PCA) was used (Piqueras-Fiszman et al., 2015).

\section{Results and discussion}

Considerable difference $(p<0.05)$ between the temperatures within growing seasons did not result in earlier ripening of fruit (Juhņeviča-Radenkova, Radenkovs, 2016 b), perhaps due to higher rainfall in $2013(24.0 \mathrm{~mm})$ than in $2012(21.2 \mathrm{~mm})$ (Table 1). In addition, there were found no significant difference $(p>0.05)$ with regard to air relative humidity.

To determine whether fruit is ready to be harvested, many physical parameters must be determined before harvesting: flesh firmness, total soluble solids and acids content, ethylene concentration, sensory parameters, iodine-starch test (Skic et al., 2016). The iodine-starch test is required to correct prognostication of harvesting date (Juhņeviča-Radenkova, Radenkovs, 2016 b). Based

Table 1. The parameters characterizing the maturity stage of apples at-harvest

\begin{tabular}{|c|c|c|c|c|c|c|c|}
\hline \multirow[t]{2}{*}{ Cultivar } & \multirow[t]{2}{*}{ Harvest } & \multicolumn{2}{|c|}{ Harvesting date } & \multicolumn{2}{|c|}{$\begin{array}{c}\text { Iodine-starch test } \\
(1-10)\end{array}$} & \multicolumn{2}{|c|}{ Streif index } \\
\hline & & 2012 & 2013 & 2012 & 2013 & 2012 & 2013 \\
\hline \multirow{2}{*}{ 'Auksis' } & $1^{\text {st }}$ & September 6 & September 10 & $5.00 \mathrm{bA} \pm 0.1$ & $3.50 \mathrm{bB} \pm 0.1$ & $0.16 a A \pm 0.01$ & $0.16 a A \pm 0.01$ \\
\hline & $2^{\text {nd }}$ & September 9 & September 14 & $5.50 a B \pm 0.1$ & $6.50 a A \pm 0.1$ & $0.10 b A \pm 0.01$ & $0.07 \mathrm{bA} \pm 0.01$ \\
\hline
\end{tabular}

Notes. Mean value for the same test and year followed by different small letters are significantly different by the least significant difference (LSD) at $p \leq 0.05$ level (differences between harvesting time). Mean value with standard deviation ( \pm ) for the same test and harvest followed by different capital letters are significantly different by the LSD at $p \leq 0.05$ level (differences between the growing seasons). Red colour of the numbers means recommended value for apple harvesting that subsequently will be kept in cold storage according to Drudze $(2003 ; 2005)$.

on literature, it is seen that cultivar such as 'Auksis' is considered to be ready for harvest when the index is 5.0. However, it is well-known that the harvesting time differs for every cultivar depending on the results of iodine-starch test, for example, for 'Elstar' it is 5.0, but for 'Golden Delicious' it is 8.0 (Brookfield et al., 1997). According to DeLong et al. (1999), is evident that no single test has proven solely adequate for assessing the physiological maturity of fruit. Combining several indices should be better than a single test, thus in total, should reduce seasonal and location-related variability. Therefore, in addition to starch-iodine tests, Streif coefficient was also used as a final harvest window for cold storage and ultra-low oxygen storage of apples. Drudze $(2003 ; 2005)$ defined and recommended the harvesting parameters for keeping the apples in cold storage based on iodine-starch index and Streif coefficient. For instance, when iodine- starch value corresponds to 5 to 7 , apples are ready for harvest. Moreover, for cold storage in air conditions, both with and without $1-\mathrm{MCP}$ treatment, the recommended Streif coefficient for autumn apple cultivars was 0.070.12 , whereas for apples stored in ULO, it was $0.08-0.19$ (Drudze, 2003, 2005). The iodine-starch index obtained for cultivar 'Auksis' showed (Table 1) that in both years of investigation, it was closest to the recommended optimal value $(6.50-5.00)$ with the exception of the results from the first harvesting in 2013 (3.50). In addition, the same trend with regard to Streif coefficient was also evident in both years of research; apples had reached an optimum maturity for harvest $(0.16-0.10)$, with the exception of the results from the $2^{\text {nd }}$ harvest in a 2013 season $(0.07)$.

As can be seen from data depicted in Table 2, in 2013, content of TSS was significantly $(p<0.01)$ higher $\left(13.16^{\circ} \mathrm{Bx}\right)$ at first harvesting compared to

Table 2. The changes in total soluble solid (TSS) content of apples during long-term storage, ${ }^{\circ} \mathrm{Bx}$

\begin{tabular}{|c|c|c|c|c|c|c|}
\hline & \multicolumn{2}{|c|}{ At-harvest } & \multicolumn{2}{|c|}{ After three months of storage } & \multicolumn{2}{|c|}{ After six months of storage } \\
\hline & $1^{\text {st }}$ harvest & $2^{\text {nd }}$ harvest & $1^{\text {st }}$ harvesting & $2^{\text {nd }}$ harvesting & $1^{\text {st }}$ harvesting & $2^{\text {nd }}$ harvesting \\
\hline $\begin{array}{c}\text { Research year } \\
2012-2013\end{array}$ & $11.27 \mathrm{aA} \pm 0.06$ & $11.57 \mathrm{aB} \pm 0.12$ & & & & \\
\hline & Cold storage & & $11.15 \mathrm{eA} \pm 0.31$ & $11.17 \mathrm{dA} \pm 0.19$ & $11.00 \mathrm{fB} \pm 0.32$ & $11.65 \mathrm{dA} \pm 0.21$ \\
\hline & Cold storage $+1-\mathrm{MCP}$ & & $11.63 \mathrm{dA} \pm 0.12$ & $11.62 \mathrm{cA} \pm 0.17$ & $11.16 \mathrm{eA} \pm 0.38$ & $11.49 \mathrm{dA} \pm 0.17$ \\
\hline & ULO1 & & $12.12 \mathrm{cB} \pm 0.19$ & $13.20 \mathrm{aA} \pm 0.19$ & $12.23 \mathrm{cA} \pm 0.27$ & $12.41 \mathrm{bA} \pm 0.10$ \\
\hline & ULO2 & & $11.46 \mathrm{dA} \pm 0.23$ & $11.47 \mathrm{cdA} \pm 0.23$ & $11.74 \mathrm{dA} \pm 0.29$ & $11.99 \mathrm{cA} \pm 0.28$ \\
\hline $\begin{array}{c}\text { Research year } \\
2013-2014 \\
\end{array}$ & $11.60 \mathrm{bA} \pm 0.17$ & $13.16 \mathrm{aA} \pm 0.15$ & & & & \\
\hline & Cold storage & & $13.32 \mathrm{aA} \pm 0.11$ & $13.44 \mathrm{aA} \pm 0.23$ & na & $12.16 \mathrm{bc} \pm 0.11$ \\
\hline & Cold storage $+1-\mathrm{MCP}$ & & $13.35 \mathrm{aA} \pm 0.19$ & $12.75 \mathrm{bB} \pm 0.36$ & $12.64 \mathrm{bA} \pm 0.35$ & $12.22 \mathrm{bA} \pm 0.10$ \\
\hline & ULO1 & & $12.90 \mathrm{bA} \pm 0.43$ & $13.17 \mathrm{aA} \pm 0.13$ & $13.19 \mathrm{aA} \pm 0.11$ & $12.56 \mathrm{bB} \pm 0.08$ \\
\hline & ULO2 & & $12.83 \mathrm{bA} \pm 0.15$ & $13.18 \mathrm{aA} \pm 0.23$ & $12.82 \mathrm{abB} \pm 0.08$ & $13.48 \mathrm{aA} \pm 0.08$ \\
\hline
\end{tabular}

Notes. Mean value with standard deviation $( \pm)$ within the same harvest and duration followed by different small letters are significantly different at $p \leq 0.05$ (LSD test). Mean value with standard deviation ( \pm ) within the same storage technology and duration followed by different capital letters are significantly different by the LSD at 0.05 level; na - fruit due to physiological and microbiological damages had not been analysed. 
$2012\left(11.57^{\circ} \mathrm{Bx}\right)$. The data of TSS positively correlated with a starch hydrolysis degree $(r=0.84)$ presented before in Table 1. However, the analysis of variance showed a significant difference $(p<0.05)$ after longterm apple storage for TSS, both for research year and harvesting time (Table 7). The results obtained indicate that apple samples (growing season 2012-2013), that were kept under ULO1 conditions, after three months of storage had reached the highest TSS concentration (the $2^{\text {nd }}$ harvest). Though, exactly opposite in 2013-2014 TSS was higher in cold storage (both the $1^{\text {st }}$ and $2^{\text {nd }}$ harvest, followed by the ULO1 and ULO2 (the $2^{\text {nd }}$ harvest). Besides, the same trend with regard to six months of storage is observed. Among storage technologies applied in this research, ULO1 (the $1^{\text {st }}$ harvest) and ULO2 (the $2^{\text {nd }}$ harvest) resulted in a more significant TSS preservation. Whereas, apple samples that were collected for the first time and kept for six months under cold storage, were not analysed due to physiological disorders. According to Hoehn et al. (2003), acceptable eating quality for 'Golden Delicious' apples should attain a minimum of $12 \%$ for total soluble solids.
To summarize, one can conclude that TSS of apple fruit is affected mainly by the growing season $(p<0.01)$, storage technology $(p<0.01)$, as well by the interaction of these factors $-p<0.01$ (Table 8). However, ULO storage and treatment with 1-MCP resulted in less pronounced soluble solids loss compared to cold storage.

Results depicted in Table 3 disclose that the highest titratable acidity (TA) was at-harvest, both for growing season and harvesting time. The analysis of variance showed that there were statistically significant difference $(p<0.01)$ between growing seasons (Table 7), thus indicating that weather conditions mainly the average air temperature determines the content of TA in apples. The same statement was presented earlier, showing that the average summer temperature strongly correlated with the content of TSS and TA(Qu, Zhou, 2016). After three months of storage, a significant decline in acidity was observed for all storage technologies tested, except for ULO2 (the $2^{\text {nd }}$ harvest). When comparing the results between storage conditions, it is apparent that the most pronounced TA loss was in fruit that was kept under cold storage (the $1^{\text {st }}$ and $2^{\text {nd }}$ harvest) and cold storage $+1-\mathrm{MCP}$ treatment.

Table 3. The changes in titratable acidity (TA) of apples during long-term storage, $\%$

\begin{tabular}{|c|c|c|c|c|c|c|}
\hline & \multicolumn{2}{|c|}{ At-harvest } & \multicolumn{2}{|c|}{ After three months of storage } & \multicolumn{2}{|c|}{ After six months of storage } \\
\hline & $1^{\text {st }}$ harvest & $2^{\text {nd }}$ harvest & $1^{\text {st }}$ harvesting & $2^{\text {nd }}$ harvesting & $1^{\text {st }}$ harvesting & $2^{\text {nd }}$ harvesting \\
\hline \multirow[t]{5}{*}{$\begin{array}{c}\text { Research year } \\
2012-2013 \\
\end{array}$} & $0.62 \mathrm{aA} \pm 0.01$ & $0.47 \mathrm{bB} \pm 0.02$ & & & & \\
\hline & Cold storage & & $0.41 \mathrm{dA} \pm 0.01$ & $0.40 \mathrm{cA} \pm 0.09$ & $0.32 \mathrm{bA} \pm 0.02$ & $0.33 \mathrm{bA} \pm 0.03$ \\
\hline & Cold storage +1 -MCP & & $0.32 \mathrm{eA} \pm 0.03$ & $0.32 \mathrm{dA} \pm 0.02$ & $0.44 \mathrm{aA} \pm 0.03$ & $0.44 \mathrm{aA} \pm 0.04$ \\
\hline & ULO1 & & $0.52 \mathrm{cA} \pm 0.05$ & $0.53 \mathrm{bA} \pm 0.01$ & $0.34 \mathrm{bA} \pm 0.01$ & $0.35 \mathrm{bA} \pm 0.02$ \\
\hline & ULO2 & & $0.54 \mathrm{cA} \pm 0.03$ & $0.42 \mathrm{cB} \pm 0.01$ & $0.44 \mathrm{aA} \pm 0.02$ & $0.36 \mathrm{bB} \pm 0.03$ \\
\hline \multirow[t]{5}{*}{$\begin{array}{c}\text { Research year } \\
2013-2014\end{array}$} & $0.84 \mathrm{aA} \pm 0.02$ & $0.84 \mathrm{aA} \pm 0.04$ & & & & \\
\hline & Cold storage & & $0.47 \mathrm{dA} \pm 0.04$ & $0.54 \mathrm{bA} \pm 0.01$ & na & $0.27 \mathrm{c} \pm 0.03$ \\
\hline & Cold storage $+1-\mathrm{MCP}$ & & $0.58 \mathrm{bcA} \pm 0.04$ & $0.62 \mathrm{aA} \pm 0.04$ & $0.33 \mathrm{bB} \pm 0.02$ & $0.42 \mathrm{aA} \pm 0.02$ \\
\hline & ULO1 & & $0.61 \mathrm{bA} \pm 0.03$ & $0.59 \mathrm{aA} \pm 0.01$ & $0.42 \mathrm{aA} \pm 0.01$ & $0.39 \mathrm{abA} \pm 0.04$ \\
\hline & ULO2 & & $0.71 \mathrm{aA} \pm 0.01$ & $0.52 \mathrm{bB} \pm 0.01$ & $0.46 \mathrm{aA} \pm 0.02$ & $0.42 \mathrm{aA} \pm 0.03$ \\
\hline
\end{tabular}

Explanations under Table 2

The same tendency was observed when analysing the samples after six months of storage; however, ULO1 conditions also led to significant reduction of organic acids. Finally, one can conclude that during storage, mainly storage technology $(p<0.01)$, harvesting time $(p<0.01)$ and the growing season $(p<0.01)$ are responsible for changes in TA (Table 8 ). Statistically positive effect of organic acid preservation perhaps due to delayed respiration process (Weber et al., 2013) was achieved when ULO2 storage was applied.

Weather conditions during the growing season may significantly affect the total phenolic content (TPC), both at-harvest and during long-term storage (Kviklys et al., 2014). Moreover, inadequate storage technology will contribute to the more pronounced quality loss. As it can be seen from data depicted in Table 4, it is obvious that the highest TPC was in fruit grown in season of 2012 compared to 2013 , besides significant difference $(p<0.01)$ was found between harvests (Table 7). Lower TPC is explained by the higher air temperature during fruit developing as well due to ripening stage at-harvest. Our observation is confirmed by Yang et al. (2013), who pointed out that the TPC found in currant berries was significantly higher in the berries grown at the higher latitude than in those grown at the lower latitude.

The TPC showed an increase after three months of storage, except for apples kept under ULO1 (the $2^{\text {nd }}$ harvest in a 2012-2013 season) and ULO2 conditions (both the $1^{\text {st }}$ and $2^{\text {nd }}$ harvest in a 2013-2014 season). The same trend of TC increase was evident for apples kept for six months. The TPC increase in particular for cold storage (the $2^{\text {nd }}$ harvest in a 2012-2013 season) and for cold storage, 1-MCP treatment, and ULO2 (the $1^{\text {st }}$ harvest in a 2013-2014 season) indicating on a lower efficiency of these technologies than ULO. It was previously reported that an increase in the TPC evidences further ripening process of fruit (Zhang et al., 2010; Ferreira Zielinski et al., 2014). Matthes and Schmitz-Eiberger (2009) stated that TPC was greatly affected by cold storage, resulting in an increase of TPC in cultivars 'Pinova', 'Topaz' and 'Golden Delicious' fruit. In addition, the same authors observed that apples stored under controlled atmosphere conditions for 4.5 months showed a slight increase in TPC, besides the degree in 
Table 4. The changes in total phenolic content (TPC) of apples during long-term storage, mg GAE $100 \mathrm{~g}^{-1} \mathrm{FW}$

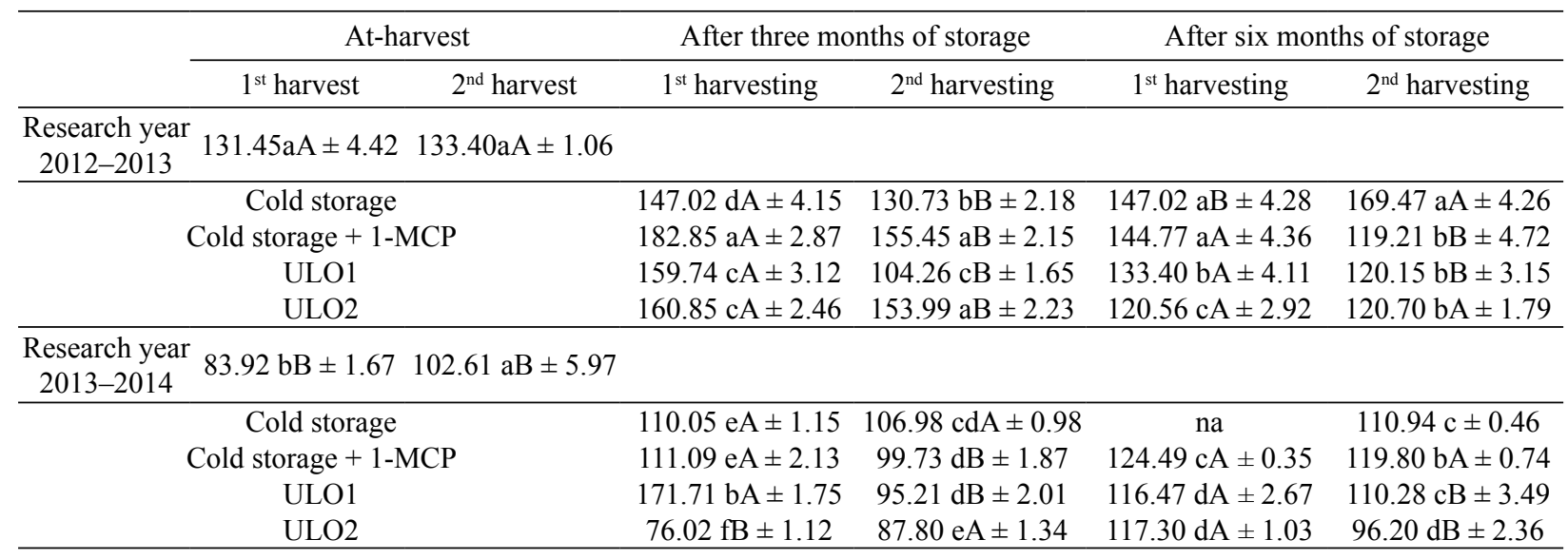

Explanations under Table 2

the increase was shown to be cultivar dependent. Barrett et al. (1991) studied the effects of controlled atmosphere storage on the phenolics of 'Delicious' apple during 180 days at $0^{\circ} \mathrm{C}$ and they established that the concentration of TPC was fairly stable.

Our findings reveal that phenolics in apple fruit were relatively stable during 6 months of ULO storage. While long-term storage of apples under normal atmosphere conditions and treatment with 1-MCP resulted in an increase of TPC. Generally, one can conclude that during storage the TPC in apple fruit are affected both by storage technology and harvesting time (as well by the interaction of these factors), though the main factors most responsible for the changes could be considered harvesting time $(p<0$.) and storage technology ( $p<$ 0.01) (Table 8).

Pectic substances are high molecular-weight compounds that are present in the cell walls of middle layers of the apples. Those substances consist of protopectin, pectin polysaccharides, and the concomitant arabinans, galactans and arabinogalactans. Protopectin is an insoluble non-starch polysaccharide that promptly moves to the soluble form during fruit ripening, thereby affecting the quality of the fruit, in particular on firmness and taste (mealiness) (Wei et al., 2010). The results obtained in this research depicted in Table 5 disclose that at the time of harvest fruit had a higher content of total pectins (TP), with the exception of the $1^{\text {st }}$ harvesting in a
2013-2014 season. The analysis of variance showed that there were significant difference $(p<0.01)$ between the growing seasons, while no differences $(p=0.10)$ were found between harvests (Table 7). Significantly lower amount of TP may be due to degree of ripeness that was only close to optimal (3.5 points out of 10 based on iodinestarch test). The content of TP in mature fruit harvested at optimal maturity stage significantly decreased during storage, irrespective of the 1-MCP treatment and ULO storage, whereas an increase in TP of fruit harvested in 2013-2014 was observed. Our observation suggests that well ripened fruit contain a higher amount of enzymes such as: pectin methylesterase (E.C 3.1.1.11), pectin lyase (E.C 4.2.2.2.) and endo- $\beta$-1.4-glucanasae (E.C 3.2.1.4), those that contribute to the de-polymerisation of pectin compounds, resulting in degradation of the cell walls (Billy et al., 2008). Although long-term storage resulted in a decrease in TP, the changes were significantly slower in fruit kept under ULO1 (an average decline for both harvests $13.17 \%$ ), followed by ULO2 conditions $(26.42 \%)$ than in cold storage $(57.17 \%)$ or cold storage $+1-\mathrm{MCP}(58.26)$ (the $1^{\text {st }}$ and $2^{\text {nd }}$ harvest in a 2012-2013 season). The same positive results of controlled atmosphere storage of nectarine (Zhou et al., 2000) and pepino apple fruit Solanum muricatum (Ait.) have been obtained by Huyskens-Keil et al. (2006). The activity of many of these enzymes, in turn, is strongly affected by controlled atmosphere conditions.

Table 5. The changes in total pectin (TP) substances of apples during long-term storage, g GALAE $100 \mathrm{~g}^{-1} \mathrm{FW}$

\begin{tabular}{|c|c|c|c|c|c|c|}
\hline & \multicolumn{2}{|c|}{ At-harvest } & \multicolumn{2}{|c|}{ After three months of storage } & \multicolumn{2}{|c|}{ After six months of storage } \\
\hline & $1^{\text {st }}$ harvest & $2^{\text {nd }}$ harvest & $1^{\text {st }}$ harvesting & $2^{\text {nd }}$ harvesting & $1^{\text {st }}$ harvesting & $2^{\text {nd }}$ harvesting \\
\hline $\begin{array}{c}\text { Research year } \\
2012-2013\end{array}$ & $0.45 \mathrm{aA} \pm 0.03$ & $0.46 \mathrm{aA} \pm 0.02$ & & & & \\
\hline & Cold storage & & $0.37 \mathrm{bA} \pm 0.01$ & $0.41 \mathrm{abA} \pm 0.02$ & $0.18 \mathrm{cA} \pm 0.02$ & $0.21 \mathrm{bA} \pm 0.01$ \\
\hline & Cold storage $+1-\mathrm{MCP}$ & & $0.38 \mathrm{abA} \pm 0.01$ & $0.37 \mathrm{bA} \pm 0.01$ & $0.18 \mathrm{cA} \pm 0.01$ & $0.20 \mathrm{bA} \pm 0.01$ \\
\hline & ULO1 & & $0.40 \mathrm{abB} \pm 0.01$ & $0.49 \mathrm{aA} \pm 0.02$ & $0.39 \mathrm{abA} \pm 0.00$ & $0.40 \mathrm{aA} \pm 0.00$ \\
\hline & ULO2 & & $0.47 \mathrm{aA} \pm 0.02$ & $0.48 \mathrm{aA} \pm 0.01$ & $0.31 \mathrm{bB} \pm 0.01$ & $0.36 \mathrm{aA} \pm 0.01$ \\
\hline $\begin{array}{c}\text { Research year } \\
2013-2014\end{array}$ & $0.31 \mathrm{aB} \pm 0.02$ & $0.40 \mathrm{aA} \pm 0.03$ & & & & \\
\hline & Cold storage & & $0.37 \mathrm{bA} \pm 0.01$ & $0.32 \mathrm{bcB} \pm 0.01$ & w & $0.35 \mathrm{a} \pm 0.01$ \\
\hline & Cold storage $+1-\mathrm{MCP}$ & & $0.35 \mathrm{bB} \pm 0.02$ & $0.41 \mathrm{abA} \pm 0.01$ & $0.35 \mathrm{bA} \pm 0.01$ & $0.37 \mathrm{aA} \pm 0.02$ \\
\hline & ULO1 & & $0.31 \mathrm{bA} \pm 0.02$ & $0.31 \mathrm{cA} \pm 0.01$ & $0.37 \mathrm{abA} \pm 0.01$ & $0.39 \mathrm{aA} \pm 0.02$ \\
\hline & ULO2 & & $0.40 \mathrm{abA} \pm 0.02$ & $0.28 \mathrm{cB} \pm 0.01$ & $0.45 \mathrm{aA} \pm 0.02$ & $0.25 \mathrm{bB} \pm 0.01$ \\
\hline
\end{tabular}

Explanations under Table 2 
In turn, the results obtained during 2013-2014 indicate, that apples collected for the first time and then kept in cold storage conditions for six months due to physiological and microbiological damage, in particular, superficial scald and green mould, were not analysed. While, likewise in the 2012-2013 in 2013-2014 we found that ULO1 (the $1^{\text {st }}$ and $2^{\text {nd }}$ harvest), as well as ULO2 (the $1^{\text {st }}$ harvest) storage, resulted in less pronounced TP loss compared to conventional cold storage or cold storage + 1-MCP. According to statistical analysis (Tables 7 and 8), one can conclude that the main factors influencing the content of TP at-harvest and within six months of storage is the growing season $(p<0.01)$ and storage technology $(p<0.01)$.
Vitamin C, including ascorbic acid and dehydroascorbic acid, is one of the most important nutritional quality indicators in many horticultural crops and has many biological activities in the human body. The content of vitamin $\mathrm{C}$ in fruits and vegetables can be influenced by various factors such as genotypic differences, pre-harvest climatic conditions and cultural practices, maturity and harvesting methods, and postharvest handling procedures. According to literature, the vitamin $\mathrm{C}$, including ascorbic and dehydroascorbic acid content in apples varies from 2 to $30 \mathrm{mg} 100 \mathrm{~g}^{-1}$

As can be seen from Tables 6 and 7, at the time of harvest in the 2013-2014, fruit had a significantly higher $(p<0.01)$ content of vitamin C than in 2012-2013.

Table 6. The changes in vitamin $\mathrm{C}$ content in apples during long-term storage, mg AAE $100 \mathrm{~g}^{-1} \mathrm{FW}$

\begin{tabular}{|c|c|c|c|c|c|c|}
\hline & \multicolumn{2}{|c|}{ At-harvest } & \multicolumn{2}{|c|}{ After three months of storage } & \multicolumn{2}{|c|}{ After six months of storage } \\
\hline & $1^{\text {st }}$ harvest & $2^{\text {nd }}$ harvest & $1^{\text {st }}$ harvesting & $2^{\text {nd }}$ harvesting & $1^{\text {st }}$ harvesting & $2^{\text {nd }}$ harvesting \\
\hline \multirow[t]{5}{*}{$\begin{array}{c}\text { Research year } \\
2012-2013\end{array}$} & $11.33 \mathrm{aB} \pm 0.06$ & $11.27 \mathrm{aB} \pm 0.06$ & & & & \\
\hline & Cold storage & & $11.85 \mathrm{~b} \pm 0.12$ & $12.74 b \pm 0.42$ & $10.80 \mathrm{bc} \pm 0.33$ & $11.36 \mathrm{a} \pm 0.21$ \\
\hline & Cold storage $+1-\mathrm{MCP}$ & & $11.41 \mathrm{~b} \pm 0.15$ & $11.25 \mathrm{~d} \pm 0.12$ & $11.38 \mathrm{a} \pm 0.38$ & $9.75 \mathrm{c} \pm 0.17$ \\
\hline & ULO1 & & $11.31 \mathrm{~b} \pm 0.21$ & $11.05 \mathrm{~d} \pm 0.31$ & $11.05 \mathrm{ab} \pm 0.27$ & $11.00 \mathrm{a} \pm 0.15$ \\
\hline & ULO2 & & $11.57 \mathrm{~b} \pm 0.18$ & $11.90 \mathrm{c} \pm 0.13$ & $11.47 \mathrm{a} \pm 0.29$ & $10.66 \mathrm{~b} \pm 0.28$ \\
\hline \multirow[t]{5}{*}{$\begin{array}{c}\text { Research year } \\
2013-2014\end{array}$} & $13.78 \mathrm{aA} \pm 0.12$ & $13.33 \mathrm{aA} \pm 0.26$ & & & & \\
\hline & Cold storage & & $10.42 \mathrm{c} \pm 0.15$ & $12.53 \mathrm{~b} \pm 0.11$ & na & $6.91 \mathrm{e} \pm 0.29$ \\
\hline & Cold storage $+1-\mathrm{MCP}$ & & $9.59 \mathrm{~d} \pm 0.09$ & $8.93 \mathrm{e} \pm 0.12$ & $7.84 \mathrm{~d} \pm 0.35$ & $7.35 \mathrm{~d} \pm 0.10$ \\
\hline & ULO1 & & $13.03 \mathrm{a} \pm 0.28$ & $13.73 \mathrm{a} \pm 0.17$ & $7.49 \mathrm{~d} \pm 0.11$ & $7.49 \mathrm{~d} \pm 0.08$ \\
\hline & $\mathrm{ULO} 2$ & & $12.86 \mathrm{a} \pm 0.02$ & $13.71 \mathrm{a} \pm 0.09$ & $10.57 \mathrm{c} \pm 0.08$ & $7.23 \mathrm{de} \pm 0.08$ \\
\hline
\end{tabular}

Explanations under Table 2

After three months of storage, the content of vitamin C in cultivar 'Auksis' apples harvested in 2012-2013 was stable and no significant differences were found between storage methods, except for cold storage. However, in the 2013-2014 season, pronounced degradation of vitamin $\mathrm{C}$ was for apples, kept under cold storage +1 -MCP (average decline for both harvests was $32.80 \%$ ), followed by cold storage $(16.72 \%)$. The same trend of decline in vitamin $\mathrm{C}$ of apples was observed after six months of storage.

The average decline in vitamin $\mathrm{C}$ content in both harvests for 2012-2013 was in the range from $1.73 \%$ (cold storage) to $6.30 \%$ (1-MCP-treated); while in $2013-2014$ from $33.23 \%$ (ULO2) to $48.16 \%$ (cold storage). Though, it should be mentioned that the most significant degradation of vitamin $\mathrm{C}$ was observed for 1-MCP-treated fruit (research year 2012-2013), while in 2013-2014 for fruit kept under cold storage conditions. Similar observations were reported by Moor et al. (2007), who pointed out that the 1-MCP influence might be yeardependent where the key driver is average air temperature during vegetation period which greatly influences fruit maturity. Moreover, different fruits display different absorption rate of 1-MCP, which may be attributed to the insoluble dry matter, or due to spatial variation in binding (Nanthachai et al., 2007). In the first year of research, the decrease in vitamin $\mathrm{C}$ indicated that $1-\mathrm{MCP}$ treatment might even facilitate fruit ripening, while in the second year 1-MCP-treated apple were contained more vitamin C than control samples (Moor et al., 2007). In terms of

Table 7. Factors that influence the changes in chemical composition before storage, data based on the multivariate analysis of variance (MANOVA)

\begin{tabular}{ccccc}
\hline Influencing factors & & The growing season & Harvesting time & The growing season $\times$ harvesting time \\
\hline \multirow{2}{*}{ Total soluble solids (TSS) } & $F$ & 370.37 & 46.44 & 9.43 \\
& $p$ & $1.56 \times 10^{-20}$ & $5.76 \times 10^{-8}$ & $4.05 \times 10^{-3}$ \\
\hline \multirow{2}{*}{ Titratable acidity (TA) } & $F$ & 74.71 & 29.12 & 42.28 \\
& $p$ & $1.19 \times 10^{-5}$ & $1.76 \times 10^{-4}$ & $1.65 \times 10^{-8}$ \\
\hline \multirow{2}{*}{ Total phenolic content (TPC) } & $F$ & 415.23 & 28.84 & 18.97 \\
& $p$ & $1.12 \times 10^{-10}$ & $1.68 \times 10^{-4}$ & $9.36 \times 10^{-4}$ \\
\hline \multirow{2}{*}{ Total pectin (TP) } & $F$ & 11.44 & 3.24 & 0.26 \\
\hline \multirow{2}{*}{ Vitamin C } & $p$ & $5.45 \times 10^{-3}$ & 0.1 & - \\
& $F$ & 74.71 & 0.04 & - \\
\hline
\end{tabular}


Table 8. Factors that influence the changes in chemical composition during storage, data based on the multivariate analysis of variance $(M A N O V A)$

\begin{tabular}{|c|c|c|c|c|c|c|c|c|}
\hline Influencing factors & & $\begin{array}{l}\text { Storage } \\
\text { technology }\end{array}$ & $\begin{array}{l}\text { The } \\
\text { growing } \\
\text { season }\end{array}$ & $\begin{array}{l}\text { Harvesting } \\
\text { time }\end{array}$ & $\begin{array}{c}\text { Storage } \\
\text { technology } \times \\
\text { the growing } \\
\text { season }\end{array}$ & $\begin{array}{c}\text { Storage } \\
\text { technology } \times \\
\text { harvesting } \\
\text { time }\end{array}$ & $\begin{array}{c}\text { The } \\
\text { growing } \\
\text { season } \times \\
\text { harvesting } \\
\text { time }\end{array}$ & $\begin{array}{c}\text { Storage } \\
\text { technology } \times \\
\text { the growing } \\
\text { season } \times \\
\text { harvesting time }\end{array}$ \\
\hline \multirow{2}{*}{ Total soluble solids (TSS) } & $F$ & 90.92 & 502.18 & 7.44 & 9.93 & 20.75 & 2.53 & 29.43 \\
\hline & $p$ & $2.25 \times 10^{-31}$ & $8.76 \times 10^{-46}$ & $7.30 \times 10^{-3}$ & $6.31 \times 10^{-6}$ & $5.47 \times 10^{-11}$ & 0.11 & $2.85 \times 10^{-7}$ \\
\hline \multirow{2}{*}{ Titratable acidity (TA) } & $F$ & 93.8 & 0 & 6.89 & 1.48 & 0.51 & 0.31 & 0.64 \\
\hline & $p$ & $7.34 \times 10^{-28}$ & $1.12 \times 10^{-24}$ & $6.40 \times 10^{-26}$ & $2.23 \times 10^{-15}$ & $2.35 \times 10^{-19}$ & 0.58 & $3.55 \times 10^{-12}$ \\
\hline \multirow{2}{*}{ Total phenolic content (TPC) } & $F$ & 122.62 & 17.58 & 630.33 & 60.57 & 102.38 & 0.01 & 91.98 \\
\hline & $p$ & $8.35 \times 10^{-21}$ & $1.39 \times 10^{-4}$ & $6.46 \times 10^{-27}$ & $2.65 \times 10^{-15}$ & $2.40 \times 10^{-19}$ & 0.93 & $3.85 \times 10^{-12}$ \\
\hline \multirow{2}{*}{ Total pectin (TP) } & $F$ & 248.71 & 19.52 & 458.98 & 68.97 & 231.41 & 165.94 & 312.4 \\
\hline & $p$ & $9.32 \times 10^{-27}$ & $6.86 \times 10^{-5}$ & $3.15 \times 10^{-24}$ & $2.85 \times 10^{-16}$ & $3.89 \times 10^{-26}$ & $3.52 \times 10^{-16}$ & $4.60 \times 10^{-21}$ \\
\hline \multirow{2}{*}{ Vitamin C } & $F$ & 24.2 & 94.68 & 292.79 & 27.98 & 24.04 & 80.08 & 56.5 \\
\hline & $p$ & $1.77 \times 10^{-9}$ & $1.22 \times 10^{-12}$ & $2.54 \times 10^{-21}$ & $2.29 \times 10^{-10}$ & $1.94 \times 10^{-9}$ & $1.50 \times 10^{-11}$ & $5.34 \times 10^{-13}$ \\
\hline
\end{tabular}

ULO storage, it was found that degradation of vitamin C appears both aerobic and anaerobic pathways (Mercali et al., 2014), thus explaining why such decline in vitamin $\mathrm{C}$ occurs in this type of storage. Analysis of variance showed (Table 8) that the content of vitamin $\mathrm{C}$ was affected both by storage conditions and harvesting time, as well as by the interaction of these factors; however, as the main factor influencing the changes in the content of vitamin $\mathrm{C}$ can be considered harvesting time $(p<0.01)$, in particular weather conditions.
Principal component analysis (PCA) was applied to better understand the relationships between the variables and the clustering group. According to PiquerasFiszman et al. (2015), to identify the most important variables or principal components (PC), the significant factor loading values higher or equal to 0.7 were used. The higher values of a variable loading, these variables have an influence in the formation of the PC score. In our case, $\mathrm{PC} 1$ and $\mathrm{PC} 2$ together explain $77.6 \%$ of the samples' variance (Fig. 2 A). All eight variables are represented in

Table 9. Loading factors of the first eight principal components from principal component analysis (PCA)

\begin{tabular}{|c|c|c|c|c|c|c|c|c|}
\hline $\begin{array}{l}\text { Loading } \\
\text { variables }\end{array}$ & $\begin{array}{l}\text { Total soluble } \\
\text { solids (TSS) }\end{array}$ & $\begin{array}{c}\text { Titratable } \\
\text { acidity (TA) }\end{array}$ & $\begin{array}{l}\text { Total phenolic } \\
\text { content (TPC) }\end{array}$ & Vitamin C & $\begin{array}{l}\text { Total pectin } \\
\text { (TP) }\end{array}$ & Temperature & $\begin{array}{l}\text { Relative } \\
\text { humidity }\end{array}$ & Precipitation \\
\hline PC1 & 0.811 & 0.24 & -0.748 & -0.483 & 0.364 & 0.973 & 0.965 & 0.966 \\
\hline PC2 & 0.136 & -0.92 & 0.385 & -0.812 & -0.3 & 0.088 & 0.019 & 0.019 \\
\hline PC3 & 0.23 & -0.193 & 0.097 & -0.033 & 0.862 & -0.106 & -0.156 & -0.156 \\
\hline PC4 & -0.27 & 0.064 & 0.453 & 0.076 & 0.129 & 0.172 & 0.195 & 0.195 \\
\hline PC5 & -0.443 & -0.015 & -0.263 & -0.234 & 0.137 & -0.02 & 0.011 & 0.011 \\
\hline PC6 & 0.048 & 0.232 & 0.09 & -0.214 & -0.003 & -0.006 & -0.064 & -0.064 \\
\hline PC7 & 0.007 & 0.004 & 0.004 & -0.008 & 0.001 & -0.072 & 0.03 & 0.03 \\
\hline \multirow[t]{2}{*}{ PC8 } & 0 & 0 & 0 & 0 & 0 & 0 & 0 & 0 \\
\hline & PC1 & PC2 & PC3 & PC4 & PC5 & PC6 & PC7 & PC8 \\
\hline $\begin{array}{l}\text { Explained } \\
\text { variance }\end{array}$ & $55.30 \%$ & $22.30 \%$ & $11.40 \%$ & $5.10 \%$ & $4.30 \%$ & $1.50 \%$ & $0.10 \%$ & $0.00 \%$ \\
\hline
\end{tabular}

PC - principal component

the biplot by a vector, and the direction and length of the vector indicates how each variable contributes to the two principal components in the plot. For instance, the first PC1, on the horizontal axis, has strong positive coefficients for the six variables. That explains why they are directed into the right half of the plot. On the other hand, PC1 also has a strong negative correlation for two variables; consequently two vectors are directed into the left edge of the plot. The largest positive correlation coefficients in the first principal component (PC1) are the sixth, eight, seventh and first elements, corresponding to the variables temperature $(0.973)$, precipitations $(0.965)$, relative humidity $(0.965)$ and TSS $(0.811)$, respectively, while strong negative correlation belongs to the variable TPC $(-0.748)$ and moderate to vitamin $\mathrm{C}(-0.483)$ (Table 9, Fig. 2 B).
Likewise, the PC2, on the vertical axis, has positive moderate correlation coefficient for the variable TPC (0.385), whereas strong negative correlation coefficient for the variables TA $(-0.92)$ and vitamin C $(-0.812)$ (Table 9). The correlation coefficients disclose that with the increasing of average air temperature the content of TSS increases. The same trend is evident for the PC2, where the temperature and TSS increase is evident with decreasing value in the vitamin $C$ and TA.

From the biplot seen (Fig. 2 A) that five wellseparated groups are clearly distinguishable, thus showing that 'Auksis' apples that were kept for six months under cold storage (both harvests in a 2012-2013 season) and apples that were 1-MCP-treated (both harvests in a 2012-2013 season) had the highest amount of TPC. In addition, it was found that vitamin C, TA and TSS was 



Notes. Letters represented in the figures indicate the types of storage: B - before storage, C - six months cold storage; $1 \mathrm{MCP}$ - 1-MCP-treated + six months cold storage. The symbol prime (') indicates on the second growing season - 2013-2014, while without a prime on the first growing season $-2012-2013$. The symbol of multiplication $(\times)$ indicates on $1-1^{\text {st }}$ harvest and $2-2^{\text {nd }}$ harvest; Tem - temperature, $\mathrm{Rh}$ - relative humidity, Pre - precipitation.

Figure 2. Standardized (A) and correlation loadings (B) biplots obtained from principal component analysis (PCA) of variables comprising the content of total soluble solids (TSS), total phenolic content (TPC), total pectins (TP), vitamin $\mathrm{C}$ (Vit C) and titratable acidity (TA)

dominant in apples before storage (both harvests in 2012-2013 season), though the ULO conditions resulted in less pronounced quality loss of 'Auksis' apples.

\section{Conclusions}

1. The results show that the higher $(p<0.05)$ temperature in $2013\left(13.6^{\circ} \mathrm{C}\right)$ than in $2012\left(12.8^{\circ} \mathrm{C}\right)$, did not result in earlier ripening of fruit, perhaps due to a larger amount of precipitation in $2013(24.0 \mathrm{~mm})$ than in $2012(21.2 \mathrm{~mm})$.

2. Total soluble solids (TSS) content of apple fruit is affected mainly by the growing season $(p<0.01)$ and storage technology $(p<0.01)$. However, ultra-low oxygen (ULO) storage and treatment with 1-methylcyclopropene (1-MCP) resulted in less pronounced soluble solids loss compared to cold storage.

3. The findings reveal that phenolics that are present in apple fruit were relatively stable during 6 months when ULO technology was applied. While normal atmosphere conditions and apple treatment with 1-MCP resulted in the increase of total phenolic content (TPC).

4. According to the results obtained, the main factors influencing the total pectin (TP) content at harvest and during six months' storage are the growing season ( $p$ $<0.01)$ and storage technology $(p<0.01)$. Considering the storage technology, the changes were significantly slower in fruit kept under ULO1 (an average decline for both harvests $13.17 \%$ ), followed by ULO2 conditions $(26.42 \%)$ than in cold storage $(57.17 \%)$ or cold storage +1 -MCP (58.26).

5. Analysis of variance showed that the content of vitamin C in cultivar 'Auksis' apples depended mainly on the weather conditions ( $p<0.01)$ (growing season), whereas post-harvest vitamin $\mathrm{C}$ losses are affected by harvesting time $(p<0.01)$ and storage technology $(p<0.01)$.

\section{Acknowledgments}

This research commissioned by Agricultural services co-operative society "Auglu nams", was performed within framework "The research of fruit storage technologies" and funded by State program "Competence Centre for Food in Latvia".

Received 30012017

Accepted 10072017

\section{References}

1. Awad M. A., De Jager A. 2003. Influences of air and controlled atmosphere storage on the concentration of potentially healthful phenolics in apples and other fruits. Postharvest Biology and Technology, 27 (1): 53-58. https://doi.org/10.1016/S0925-5214(02)00189-8

2. Bai J., Baldwin E. A., Goodner K. L., Mattheis J. P., Brecht J. K. 2005. Response of four apple cultivars to 1-methylcyclopropene treatment and controlled atmosphere storage. HortScience, 40 (5): 1534-1538.

3. Bangerth F. K., Song J., Streif J. 2012. Physiological impacts of fruit ripening and storage conditions on aroma volatile formation in apple and strawberry fruit: a review. HortScience, 47 (1): 4-10.

4. Barrett D. M. 1991. Changes in 'Delicious' apple browning and softening during controlled atmosphere storage. Journal of Fruit Quality, 14: 443-453. https://doi.org/10.1111/j.1745-4557.1991.tb00085.x

5. Billy L., Mehinagic E., Royer G., Renard C. M. G. C., Arvisenet G., Prost C., Jourjon F. 2008. Relationship between texture and pectin composition of two apple cultivars during storage. Postharvest Biology and Technology, 47 (3): 315-324. https://doi.org/10.1016/j.postharvbio.2007.07.011

6. Brookfield P., Murphy P., Harker R., MacRae E. 1997. Starch degradation and starch pattern indices; interpretation and relationship to maturity. Postharvest Biology and Technology, 11 (1): 23-30.

https://doi.org/10.1016/S0925-5214(97)01416-6 
7. DeLong J. M., Prange R. K., Harrison P. A., Schofield R. A., DeEll J. R. 1999. Using the Streif index as a final harvest window for controlled-atmosphere storage of apples. HortScience, 34 (7): 1251-1255.

8. Drudze I. 2003. Investigations of harvest maturity and suitability for storage of some apple cultivars in Latvia. Acta Horticulturae, 599: 631-635. https://doi.org/10.17660/ActaHortic.2003.599.82

9. Drudze I. 2005. Harvest maturity and storage life investigations on Latvian apple cultivars. Latvian Journal of Agriculture, 8: 306-310.

10. Ferreira Zielinski A. A., Alberti A., Maia Braga C., Marques da Silva K., Giovanetti Canteri M. H., Igarashi Mafra L., Granato D., Nogueira A., Wosiacki G. 2014. Effect of mash maceration and ripening stage of apples on phenolic compounds and antioxidant power of cloudy juices: a study using chemometrics. LWT - Food Science and Technology, 57 (1): 223-229. https://doi.org/10.1016/j.lwt.2014.01.029

11. Hewett E. W. 2006. An overview of preharvest factors influencing postharvest quality of horticultural products. International Journal of Postharvest Technology and Innovation, 1 (1): 4-15.

https://doi.org/10.1504/IJPTI.2006.009178

12. Hoehn E., Gasser F., Guggenbühl B., Künsch U. 2003. Efficacy of instrumental measurements for determination of minimum requirements of firmness, soluble solids, and acidity of several apple varieties in comparison to consumer expectations. Postharvest Biology and Technology, 27 (1): 27-37.

https://doi.org/10.1016/S0925-5214(02)00190-4

13. Huyskens-Keil S., Prono-Widayat H., Lüdders P., Schreiner M. 2006. Postharvest quality of pepino (Solanum muricatum Ait.) fruit in controlled atmosphere storage. Journal of Food Engineering, 77 (3): 628-634. https://doi.org/10.1016/j.jfoodeng.2005.07.028

14. Johnston J. W., Hewett E. W., Hertog M. L. A. T. M., Harker F. R. 2002. Harvest date and fruit size affect postharvest softening of apple fruit. Journal of Horticultural Science and Biotechnology, 77 (3): 355-360. https://doi.org/10.1080/14620316.2002.11511505

15. Juhnevica-Radenkova K., Radenkovs V., Seglina D. 2016. Influence of 1-MCP treatment and storage conditions on the development of microorganisms on the surface of apples grown in Latvia. Zemdirbyste-Agriculture, 103 (2): 215-220 https://doi.org/10.13080/z-a.2016.103.028

16. Juhņeviča-Radenkova K., Radenkovs V. 2016 (a). Assessment of shelf-life ability of apples cv. 'Auksis' after long-term storage under different conditions. Journal of Horticultural Research, 24 (2): 37-47. https://doi.org/10.1515/johr-2016-0019

17. Juhņeviča-Radenkova K., Radenkovs V. 2016 (b). Influence of 1-methylcyclopropene and ULO conditions on sensory characteristics of apple fruit grown in Latvia. Journal of Horticultural Research, 24 (1): 37-46. https://doi.org/10.1515/johr-2016-0005

18. Kevers C., Falkowski M., Tabart J., Defraigne J. O., Dommes J., Pincemail J. 2007. Evolution of antioxidant capacity during storage of selected fruits and vegetables. Journal of Agricultural and Food Chemistry, 55 (21): 8596-8603. https://doi.org/10.1021/jf071736j

19. Kingston C. M. 2010. Maturity indices for apple and pear. Horticultural Reviews, 13: 407-432. https://doi.org/10.1002/9780470650509.ch10

20. Kviklys D., Liaudanskas M., Janulis V., Viškelis P., Rubinskiene M., Lanauskas J., Uselis N. 2014. Rootstock genotype determines phenol content in apple fruits. Plant, Soil and Environment, 60 (5): 234-240.
21. Matthes A., Schmitz-Eiberger M. 2009. Polyphenol content and antioxidant capacity of apple fruit: effect of cultivar and storage conditions. Journal of Applied Botany and Food Quality, 157 (82): 152-157.

22. Mercali G. D., Schwartz S., Marczak L. D. F., Tessaro I. C., Sastry S. 2014. Effect of the electric field frequency on ascorbic acid degradation during thermal treatment by ohmic heating. Journal of Agricultural and Food Chemistry, 62 (25): 5865-5870. https://doi.org/10.1021/jf500203u

23. Moor U., Karp K., Põldma P., Starast M. 2007. Effect of 1-MCP treatment on apple biochemical content and physiological disorders. Acta Agronomica Hungarica, 55 (1): $61-70$. https://doi.org/10.1556/AAgr.55.2007.1.7

24. Nanthachai N., Ratanachinakorn B., Kosittrakun M., Beaudry R. M. 2007. Absorption of 1-MCP by fresh produce. Postharvest Biology and Technology, 43 (3): 291-297. https://doi.org/10.1016/j.postharvbio.2006.10.003

25. Piqueras-Fiszman B., Ares G., Tomasco P. V. 2015. An introduction to sensory evaluation techniques. Nollet L. M. L., Toldra F. (eds.). Handbook of food analysis ( $3^{\text {rd }}$ ed.), p. 65-79. https://doi.org/10.1201/b18668-7

26. Qu Z., Zhou G. 2016. Possible impact of climate change on the quality of apples from the major producing areas of China. Atmosphere, 7 (9): 1-18. https://doi.org/10.3390/atmos7090113

27. Raffo A., Kelderer M., Paoletti F., Zanella A. 2009. Impact of innovative controlled atmosphere storage technologies and postharvest treatments on volatile compound production in cv. Pinova apples. Journal of Agricultural and Food Chemistry, 57 (3): 915-923. https://doi.org/10.1021/jf802054y

28. Shelukhina P., Fedichkina G. 1994. A rapid method for quantitative determination of pectic substances. Acta Botanica Neerlandica, 43 (2): 205-207. https://doi.org/10.1111/j.1438-8677.1994.tb00745.x

29. Singleton V. L., Orthofer R., Lamuela-Raventòs R. M. 1999. Analysis of total phenols and other oxidation substrates and antioxidants by means of folin-ciocalteu reagent. Methods in Enzymology, 299: 152-178. https://doi.org/10.1016/S0076-6879(99)99017-1

30. Sisler E. C., Dupille E., Serek M. 1996. Effect of 1-methylcyclopropene and methylenecyclopropane on ethylene binding and ethylene action on cut carnations. Plant Growth Regulation, 18: 79-86. https://doi.org/10.1007/BF00028491

31. Skic A., Szymańska-Chargot M., Kruk B., Chylińska M., Pieczywek P. M., Kurenda A., Zdunek A., Rutkowski K. P. 2016. Determination of the optimum harvest window for apples using the non-destructive biospeckle method. Sensors (Switzerland), 16 (5): 1-15. https://doi.org/10.3390/s16050661

32. Tano K., Oulé M. K., Doyon G., Lencki R. W., Arul J. 2007. Comparative evaluation of the effect of storage temperature fluctuation on modified atmosphere packages of selected fruit and vegetables. Postharvest Biology and Technology, 46 (3): 212-221. https://doi.org/10.1016/j.postharvbio.2007.05.008

33. Thilakarathna S. H., Rupasinghe H. P. V. 2013. Flavonoid bioavailability and attempts for bioavailability enhancement. Nutrients, 5 (9): 3367-3387. https://doi.org/10.3390/nu5093367

34. Vilaplana R., Valentines M. C., Toivonen P., Larrigaudiere C. 2006. Antioxidant potential and peroxidative state of 'Golden Smoothee' apples treated with 1-methylcyclopropene. Journal of the American Society for Horticultural Science, 131 (1): 104-109. 
35. Wawrzyńczak A., Jóźwiak Z., Rutkowski K. 2007. The influence of storage conditions and 1-MCP treatment on ethylene evolution and fruit quality in 'Gala' apples. Vegetable Crops Research Bulletin, 66 (1): 187-196. https://doi.org/10.2478/v10032-007-0021-9

36. Weber A., Thewes F. R., Schorr M. R. W., de Gasperin A. R., Venturini T. L., Brackmann A. 2013. 'Gala', 'Royal Gala' and 'Brookfield' apples stored under ultra-low oxygen and two temperatures. Bioscience Journal, 29 (6): 1887-1895.

37. Wei J., Ma F., Shi S., Qi X., Zhu X., Yuan J. 2010. Changes and postharvest regulation of activity and gene expression of enzymes related to cell wall degradation in ripening apple fruit. Postharvest Biology and Technology, 56 (2): 147-154.

https://doi.org/10.1016/j.postharvbio.2009.12.003
38. Yang B., Zheng J., Laaksonen O., Tahvonen R., Kallio H. 2013. Effects of latitude and weather conditions on phenolic compounds in currant (Ribes spp.) cultivars. Journal of Agricultural and Food Chemistry, 61: 3517-3532. https://doi.org/10.1021/jf4000456

39. Zhang Y., Li P., Cheng L. 2010. Developmental changes of carbohydrates, organic acids, amino acids, and phenolic compounds in 'Honeycrisp' apple flesh. Food Chemistry, 123 (4): 1013-1018.

https://doi.org/10.1016/j.foodchem.2010.05.053

40. Zhou H. W., Lurie S., Lers A., Khatchitski A., Sonego L., Ben Arie R. 2000. Delayed storage and controlled atmosphere storage of nectarines: two strategies to prevent woolliness. Postharvest Biology and Technology, 18 (2): $133-141$.

https://doi.org/10.1016/S0925-5214(99)00072-1

ISSN 1392-3196 / e-ISSN 2335-8947

Zemdirbyste-Agriculture, vol. 104, No. 4 (2017), p. 359-368

DOI 10.13080/z-a.2017.104.046

\title{
Laikymo technologijų ịtaka veislès 'Auksis' obuolių cheminei sudèčiai
}

\author{
V. Radenkovs, K. Juhnevica-Radenkova \\ Latvijos žemès ūkio universiteto Sodininkystės institutas
}

\section{Santrauka}

Tyrimo metu vertinta apdorojimo 1-metilciklopropenu (1-MCP) ir itin mažos koncentracijos deguonies (ULO) kontroliuojamos atmosferos sąlygomis įtaka 2,0\% $\mathrm{CO}_{2}$ bei $1,0 \% \mathrm{O}_{2}$ (ULO1) ir 2,5\% $\mathrm{CO}_{2}$ bei $1,5 \% \mathrm{O}_{2}$ (ULO2) vienos populiariausių obels veislès 'Auksis' vaisių cheminès sudèties pokyčiams ilgalaikio saugojimo metu. Tyrimas atliktas 2012-2014 m. Latvijos žemès ūkio universiteto Dobelès sodininkystès ir daržininkystės institute. Jo rezultatai parodè, kad daugeliu atvejų veislès 'Auksis' obuolių cheminè sudètis priklausè nuo oro sąlygų (auginimo sezono) ir saugojimo technologijų. Vertinant vaisių saugojimo technologijas nustatyta, kad tirpios kietosios dalelès ilgiau išsilaikè, kai buvo taikytos ULO sąlygos ir juos apdorojus 1-MCP. Be to, nustatyta, kad veislès ‘Auksis' obuoliuose esantys polifenoliai išlieka nepakitę po šešių mẻnesių laikymo ULO sąlygomis. Tačiau dèl tolesnio nokimo proceso kontrolinio varianto ir 1-MCP apdorotuose obuoliuose polifenolių kiekis padidejo. Vaisių skynimo laikas yra pagrindinis veiksnys, turintis ịtakos suminiam pektino kiekiui, o šešių mėnesių saugojimo metu pagrindiniai veiksniai, turintys itakos pektino kiekiui, buvo auginimo sezonas ir saugojimo technologijos. Dispersijos analizè parodè, kad vitamino C kiekis veislès ‘Auksis' obuoliuose daugiausia priklausè nuo oro sąlygų, o vitamino C nuostoliai po derliaus nuėmimo priklausè nuo skynimo laiko ir saugojimo technologijos.

Reikšminiai žodžiai: 'Auksis', fenoliai, itin maža deguonies koncentracija, Malus domestica, skynimo laikas, vitaminas $\mathrm{C}$. 